\title{
Resposta a Paul Lovejoy
}

\author{
João José Reis*
}

Em artigo publicado no número 28 da Topoi, intitulado "Jihad na África Ocidental durante a 'Era das Revoluçóes', Paul Lovejoy se propóe a criticar Eric Hobsbawm e Eugene Genovese por não terem incluído determinados eventos africanos em suas reflexóes a respeito da Era das Revoluçóes e das revoltas escravas nas Américas, e na Bahia em particular. No caso de Hobsbawm, alega, inclusive, que já haveria bibliografia suficiente sobre o assunto na época em que publicou (em 1962) sua obra The Age of Revolution, 1789-1848. No seu prefácio, Hobsbawm, precavido, chamava a atenção que seu livro não era "narrativa detalhada", mas uma síntese interpretativa que tinha como alvo uma espécie de "leitor ideal" que seria o "cidadão inteligente e educado", não o especialista. Ele já previa "os inevitáveis escorços de que os especialistas lamentarão."1

O lamento publicado na Topoi por Paul Lovejoy levou mais de 50 anos para ser feito. O interessante é que a África que este historiador tenta resgatar na crítica a Hobsbawm não se encontra totalmente ausente de The Age of Revolution, o que Lovejoy negligencia informar ao leitor de seu artigo. O tema é o mesmo, embora dentro daquele espírito de síntese anunciado e executado por Hosbsbawm. Senão, leiam:

Os comerciantes muçulmanos, que monopolizavam virtualmente o comércio do interior da África com o mundo exterior e o multiplicou, ajudaram a trazer o Islã à atenção de novos povos. O tráfico de escravos, que destruiu a vida comunitária, fê-lo atraente, pois o Islã é um poderoso meio de reintegração de estruturas sociais. Ao mesmo tempo a religião maometana era atraente para sociedades semifeudais e militaristas do Sudão, e seu senso de independência, militância e superioridade a transformou num útil contrapeso à escravidão. Negros muçulmanos se fizeram maus escravos: os haussás (e outros sudaneses) que foram importados para a Bahia (Brasil) se revoltaram nove vezes entre 1807 e o grande levante de 1835, até que, com efeito, foram na sua maioria mortos ou deportados de volta à África. Os escravistas aprenderam a evitar a importação dessas áreas, que tinham sido abertas apenas recentemente para o tráfico. ${ }^{2}$

DOI - http://dx.doi.org/10.1590/2237-101X016030019

* Doutor em história pela University of Minnesota, EUA, professor titular da Universidade Federal da Bahia e bolsista de produtividade científica do CNPq, nível 1A. Salvador, BA, Brasil. E-mail: jjreis@ufba.br.

${ }^{1}$ HOBSBAWM, Eric. The Age of Revolution, 1789-1848. Nova York: Abacus, 1977 [orig. 1962]. p. 11, 12.

${ }^{2}$ Idem, p. 273-274. 
O historiador inglês enfatiza o protagonismo haussá, o que não é correto para todo o ciclo de revoltas baianas, haja vista a atividade dos nagôs islamizados — e não só destes nos mais de 30 levantes e conspiraçóes do período; nem foram os rebeldes "na sua maioria mortos ou deportados [da Bahia] de volta à África”; nem os escravistas baianos deixaram de importar escravos "dessas áreas" após 1835, pois compravam o que o mercado lhes oferecia. Mas não é o caso de corrigir Hobsbawm a essa altura. A questão é corrigir Lovejoy. Pois ele escreve que tanto Hobsbawm como Genovese "tiveram papel fundamental na inclusão das revoltas escravas como parte da 'era das revoluçôes", mas que sua "intenção [de Lovejoy] é enfatizar o papel do jihad da África Ocidental nesse contexto" (p. 26). O leitor terá percebido que há em Hobsbawm pelo menos uma dose de Lovejoy, em particular sua ênfase na militância e inadaptabilidade de escravos muçulmanos à escravidão na Bahia. Hobsbawm retirou sua informação sobre as revoltas baianas da obra de Artur Ramos, As culturas negras no Novo Mundo. E aqui há mais coisa ao gosto de Lovejoy porque Ramos, seguindo Nina Rodrigues, escreveu: "Na Bahia, essas insurreiçôes foram nada mais, nada menos, do que a continuaçáo das longas e repetidas lutas religiosas e de conquista levadas a efeito pelos negros islamizados no Sudáo" 3. Isso indica que a tese geral de Lovejoy não é bem uma novidade e que sua exegese de Hobsbawm leva o leitor a pensar que a África dos haussás estava ausente do autor que ele critica. Náo só estava presente como estava, de algum jeito, do lado do crítico!

Quanto a Eugene Genovese, estamos em face de um autor que escreveu um livro especificamente sobre revoltas escravas nas Américas, publicado 35 anos atrás. ${ }^{4}$ Em resumo, a tese de Genovese é que essas revoltas se dividem em duas fases, uma antes, outra depois da Revolução do Haiti (1791-1804). Antes, elas buscavam a restauração de modos de vida africanos, depois seriam abolicionistas, na trilha do Haiti, que por sua vez teria se inspirado nos ideais libertários da Revolução Francesa. Já indiquei há muito tempo a insuficiência dessa tese - e antes de mim Stuart Schwartz - no que diz respeito às revoltas escravas baianas. ${ }^{5}$ Lovejoy chega a escrever, numa ligeira nota de seu artigo da Topoi (p. 25, nota 5), que Genovese relacionou-as diretamente aos mesmos episódios de que é acusado de desprezar na história africana. Cito Genovese, que não é táo ligeiro: "Por todas as Américas, escravos muçulmanos ganharam a reputação por serem especialmente rebeldes. A ideologia político-

\footnotetext{
${ }^{3}$ RAMOS, Artur. As culturas negras no Novo Mundo. São Paulo: Companhia Editora Nacional, 1979 [orig. 1937] p 214; e RODRIGUES, Nina. Os africanos no Brasil. 4 ed. São Paulo: Companhia Editora Nacional, 1976, p. 38. ${ }^{4}$ GENOVESE, Eugene D. From Rebellion to Revolution: Afro-American Slave Revolts in the Making of the New World. Nova York: Vintage, 1979.

${ }^{5}$ REIS, Joáo José. Um balanço dos estudos sobre as revoltas escravas da Bahia. In: REIS, João José (Ed.). Escravidão e invenção da liberdade: estudos sobre o negro no Brasil. Sáo Paulo: Brasiliense, 1988. p. 128-129; e SCHWARTZ, Stuart. Sugar Plantations in the Formation of Brazilian Society: Bahia, 1550-1835. Cambridge: Cambridge University Press, 1985. p. 473. Minha afinidade com as ideias de Genovese está noutra parte: seu conceito de paternalismo enquanto ideologia de dominação de classe. Ver, entre várias obras em que aquele autor trata do assunto, Roll Jordan Roll: The World the Slaves Made. Nova York: Pantheon, 1974.
} 
-religiosa que trouxeram da África Ocidental mal prepararam a eles para a escravização sob os infiéis, a cujo poder eles eram supostos de resistir." Mais adiante, após mencionar o jihad fulani iniciado em 1804, Genovese afirma que haussás e iorubás ${ }^{6}$, embora hostis na África, teriam se unido na Bahia por questóes que "provavelmente incluíam um condicionamento psicológico de seu passado e presente urbano em combinação com o atrativo do Islá como uma força organizacional". ' Então não é verdade que Genovese "ignora qualquer perspectiva de fundo religioso influenciada pelo Islā" (p. 63), segundo escreve Lovejoy, a essa altura já esquecido da nota 5 no início do artigo da Topoi.

Esquecimento é o que não falta no texto de Lovejoy, que solicita especificidade mas olvida invocar ou despreza os momentos específicos em que os dois autores criticados invocam processos e eventos que ele diz estarem ausentes de suas obras. Pode ser pouco, pode ser insuficiente, até equivocado, no entanto estão lá.

Paul Lovejoy gasta muitas palavras de seu artigo a desacreditar minha interpretação - e secundariamente a de distintos estudiosos — da Revolta dos Malês em 1835, além de outros temas ancilares de que tratei. Mas nesse esforço, ele também distorce ou omite o que escrevi porque me leu mal, ou sequer leu, embora referencie em suas notas de rodapé títulos que alega ter consultado, e muitos, inclusive escritos em português, língua que, tem-se a impressão, ainda não aprendeu a ler direito.

Vamos seguir a ordem em que os assuntos aparecem no texto às vezes tortuoso de Lovejoy. Na página 27 ele reúne um grupo de historiadores que escreveram, uns mais do que outros, sobre as revoltas baianas (João Reis, Stuart Schwartz, Michael Gomez e Sylviane Douf), concluindo: "Porém essas contribuiçôes não inserem os eventos nas Américas no contexto dos jihad e, particularmente, nas transformações do Sudão Central." Não vou comentar os demais autores maltratados: falo por mim. ${ }^{8}$ Escrevi sobre essas "transformaçôes" - e se trata do jihad em território haussá e seus desdobramentos em território iorubá e na Bahia em diversas ediçôes de meu livro Rebeliāo escrava no Brasil, mais longamente na edição revista e ampliada de 2003, que Lovejoy afirma ter consultado. Numa conta talvez conservadora, dedico pelo menos 10\% do meu livro ao background africano dos malês, a maior parte (mas não só) aos eventos que produziram a maciça presença de muçulmanos na Bahia. Somente no início do sexto capítulo, 17 páginas são destinadas aos acontecimentos no Sudão central e no território iorubá, especificamente; ao longo do livro o vocábulo jihad aparece muitas vezes em 34 páginas; referência às açôes do líder do jihad de 1804, Usuman dan Fodio, em

\footnotetext{
${ }^{6}$ Uso o termo iorubá ao longo deste artigo, mas esclareço que na África do tempo dos malês não existia uma identidade "iorubá" como tal para o conjunto da populaçáo hoje assim considerada.

${ }^{7}$ GENOVESE, Eugene D., op. cit., 1979, p. 29 e 30.

${ }^{8}$ Mas, a propósito, ver SCHWARTZ, op. cit., p. 474; DIOUF, Sylviane. Servants of Allah: African Muslims Enslaved in the Americas. Nova York e Londres: New York University Press, 1998. p. 158163; GOMEZ, Michael A. Black Crescent: The Experience and Legacy of African Muslims in the Americas. Cambridge: Cambridge University Press, 2005. p. 110-113.
} 
24 páginas, que inclui muitas referências a seu manual de como fazer a guerra santa segundo os mais rigorosos preceitos islâmicos; o líder dos muçulmanos iorubás, Solagberu é mencionado em oito páginas; o Califado de Sokoto emerge em 18 páginas; a cidade iorubá de Ilorin, onde vou buscar a origem dos malês na África (dica primeiramente sugerida por Nina Rodrigues), ${ }^{9}$ é aludida em 30 páginas do livro; o historiador iorubá Samuel Johnson (que Lovejoy apresenta como novidade!, p. 57), é mencionado em 13 páginas; o viajante britânico Hugh Clapperton, em 15 páginas, e seu assistente Richard Lander, em 13 - cujos relatos são também recomendados por Lovejoy para que se conheça a África dos malês e mussulmis. Contei aqui apenas páginas que contêm referências diretas feitas a esses assuntos e autores, e me reporto a elas apenas a título de exemplo. Entre fontes primárias e secundárias africanistas sobre temas relacionados com a África muçulmana e o país iorubá, consultei, e cito sempre de modo específico, em torno de 100 títulos, devidamente listados na bibliografia do livro. Chega a ser divertido ler em Lovejoy que diversos autores, com destaque para ele próprio, claro, mas não eu, "analisaram a origem africana dos participantes do levante dos malês" (p. 56-57). ${ }^{10}$

Quem me ler encontrará, a cada passo da narrativa, nos momentos que considero pertinentes, a presença da África como possibilidade interpretativa para os eventos baianos. E na última edição do livro, de 2003, me empenho ainda mais nesse sentido do que nas anteriores, se comparada, por exemplo, à edição em inglês, sobre a qual, aliás, Lovejoy, apesar de "reservas sobre minhas conclusôes", escreveu: "Ao contrário de virtualmente todo o gênero de estudos da escravidão, Reis leva a história africana a sério." ${ }^{\prime 11}$ Esqueçam, porém, o que ele escreveu. A questão agora não é, como Lovejoy pretende, que eu desconheça a África dos malês ou deixe de interpretá-la como fator ponderável em minha narrativa da revolta de 1835; o problema é seu desejo de se impor como a última palavra sobre o tema, não importa se para isso precise desobedecer procedimento elementar da crítica intelectual, que é reconhecer e expor honestamente os dados e interpretaçóes do oponente. ${ }^{12}$

Sobre o tema geral proposto por Lovejoy em seu artigo, transcrevo trecho de um capítulo que recentemente publiquei, em parceria com Laura de Mello e Souza, no qual resumo o que, com palavras diferentes, já venho dizendo há muito tempo:

\footnotetext{
${ }^{9}$ RODRIGUES, Nina, op. cit., p. 40.

${ }^{10} \mathrm{Um}$ autor que Lovejoy reconhece estar no caminho justo é Manuel Barcia. Sobre ele, escreve: "Como Barcia observa, o jihad teve um impacto dramático sobre Cuba e Bahia, embora o autor não documente esse impacto" (p. 64). Se náo documenta, como aprovar a conclusão de que o impacto foi de fato "dramático"? Não percebo - e não cabe aqui entrar no mérito do trabalho de Barcia.

${ }^{11}$ Paul Lovejoy em resenha de João José Reis, Slave Rebellion in Brazil: The Muslim Uprising of 1835 in Bahia. Baltimore: The Johns Hopkins University Press, 1993. In: The International Journal of African Historical Studies, v. 30, n. 1, p. 183, 1997. No original: "Unlike virtually the whole genre of slave studies, Reis takes African history seriously."

${ }^{12}$ Uma crítica de bom leitor — que me levou a burilar meus argumentos, não a mudá-los fundamentalmente — de duas edições anteriores de meu livro é a de COSTA e SILVA, Alberto da. Sobre a rebelião de 1835 na Bahia. Revista Brasileira, ano viii, n. 31, p. 9-33, 2002.
} 
Se a Era da Revolução foi principalmente um fenômeno atlântico originado na Europa, na América do Norte e no Caribe, as ideologias de protesto das rebelióes escravas baianas vieram, sobretudo, da África Ocidental. A maioria dos escravos rebeldes na região [Bahia] era de falantes de haussá e iorubá que tinham experimentado conflitos devastadores em suas terras, particularmente as guerras civis que levaram à queda do poderoso reino de Oyo e o jihad liderado pelos fulanis, iniciado em 1804 no território haussá, que levou à criação do califado de Sokoto em 1809. Indisputavelmente uma Era da Revolução nesta parte da África Ocidental, essas guerras levaram ao colapso de reinos centenários e à formação de novos estados, um deles uma poderosa federação muçulmana. Elas tiveram repercussóes no Brasil, particularmente na Bahia, [...] porque os conflitos africanos, que se prolongaram por décadas, ocasionaram a morte, a migração, o deslocamento e a escravização de milhares de pessoas capturadas nas batalhas ou sequestradas de suas cidades, muitas das quais eram vendidas a negociantes de escravos nos portos do golfo de Benim na costa atlântica. ${ }^{13}$

Eu já percebera, sem entrar em detalhes, o aborrecimento de Lovejoy neste artigo (p. 35, 63). Mesmo sem nunca ter lido o trecho acima, seria ainda impróprio ele incluir meu nome na seguinte frase: "O envolvimento [dos iorubás] em eventos [rebeldes] nas Américas foi mais do que uma extensão da resistência escrava associada à 'era das revoluçôes', como descrito por estudiosos influenciados pela tradição inaugurada por Hobsbawm e Genovese, a exemplo dos historiadores Jane Landers, Matt Childs e João Reis" (p. 40). E conclui retoricamente: "Como podemos compreender como os africanos pensavam sobre seu envolvimento nesses eventos se não levarmos em consideração suas experiências prévias?” (p. 40) Náo podemos, concordo, embora sem me deixar possuir por uma monomania afrocêntrica, mas compreendendo que também se deva considerar, e fundamentalmente, as experiências do tráfico, da escravidão, da formação pelos africanos de novas redes de sociabilidade, estratégias políticas e ressignificações culturais deste lado do Atlântico. É o que busco fazer em Rebelião escrava no Brasil. Nesse livro, em nenhum momento me reporto a Hobsbawm ou Genovese na acepção atribuída por Lovejoy, mas digo, quanto à revolta de 1835: "Ao contrário do que ocorrera no Haiti quarenta anos antes, as ideologias revolucionárias europeias que proclamavam o direito universal à liberdade e à cidadania passavam ao largo da mentalidade desses homens [os malês] formados na África e na Bahia." ${ }^{14} \mathrm{E}$ me remeto ao Islã, mas não só a este, para entender aquela mentalidade.

\footnotetext{
${ }^{13}$ MELLO e SOUZA, Laura de; REIS, João José. Popular Movements in Colonial Brazil. In: CANNY, Nicholas; MORGAN, Philip (Orgs.). The Oxford Handbook of the Atlantic World, 1450-1850. Oxford e Nova York: Oxford University Press, 2011. p. 563-564. Naturalmente, a parte sobre as revoltas baianas foi escrita por mim.

${ }^{14}$ REIS, João José. Rebelião escrava. São Paulo: Companhia das Letras, 2003, p. 268. O leitor perdoará a insistência em referir-me a este livro ao longo deste texto, mas espero que entenda por que o faço.
} 
Seguindo uma tradição que remonta a Nina Rodrigues e passa por Pierre Verger, já demonstrei que o grande influxo de escravos muçulmanos para a Bahia aconteceu na virada do século XIX em decorrência do jihad de 1804 e seus desdobramentos entre vizinhos do país haussá, que foi seu epicentro. Antes do jihad a presença de africanos traficados para a Bahia dessa região através do Atlântico era insignificante, ou seja, os estados haussás contra os quais Usuman dan Fodio e seus sucessores lutaram, estes sim forneceram pouca gente para o tráfico transatlântico, o que está implícito na análise de Lovejoy (p. 52). Os conflitos deslanchados e o regime fundado por Dan Fodio foram responsáveis pelo incremento do tráfico do Sudão Central para o litoral. Lovejoy acha que o "Islá era um fator que desencorajava a venda de escravos para as Américas", e pouco adiante: "Fatores religiosos e ideológicos impediam que os muçulmanos vendessem escravos para os europeus ou para comerciantes associados aos mercados transatlânticos" (p. 49). Ele trabalha com a hipótese de que a deportação de tão grande número de muçulmanos para a Bahia seria uma exceção, mas não explica o porquê da excepcionalidade (p. 49).

Segundo Lovejoy o jihad e a pressão da Inglaterra, combinados, seriam responsáveis pela retração do tráfico na Costa da Mina (golfo do Benim) em favor do tráfico na África Centro-Ocidental. Ele joga com números, então me permitam entrar nesse jogo. O tráfico da Costa da Mina (golfo do Benim), somado ao da África Centro-Ocidental, vitimou, na segunda metade do século XVIII, cerca de 2 milhôes e 27 mil africanos, dos quais apenas $27 \%$ foram embarcados em entrepostos da primeira região para as Américas. Já entre 1801 e 1850, em torno de 2 milhóes 331 mil cativos foram embarcados nas duas regióes, e da Costa da Mina não mais que $18 \%$ destes. No entanto, o cálculo a ser feito é se houve uma redução considerável de embarques na Costa da Mina entre um e outro período, e o resultado é que houve uma redução, que não se pode definir como alentada, de cerca de 550 mil para cerca de 411 mil. Ou seja, dos estimados 960.520 cativos transportados da Costa da Mina através do Atlântico entre 1750 e 1850, 43\% o foram entre 1801 e 1850, uma desvantagem de 7\% em relaçáo aos 50 anos anteriores. Isso sugere que o tráfico transatlântico da Costa da Mina, onde embarcavam cativos da regiáo afetada pelo jihad, não declinou substantivamente, mesmo tendo diminuído as regióes consumidoras desses cativos nas Américas, agora praticamente reduzidas ao Brasil e o Caribe espanhol (com destaque para Cuba) ao longo da primeira metade do Oitocentos. ${ }^{15}$ Retirados do banco de dados online Slave Voyages, esses dados, no entanto, subestimam o intenso tráfico brasileiro - sobretudo para a Bahia, o maior consumidor de escravos da Costa da Mina porque, para o período que vai de 1817-1818 (proibição do tráfico luso-brasileiro acima da linha do Equador) a 1831 (proibiçáo total do tráfico brasileiro), os negreiros declaravam

\footnotetext{
${ }^{15}$ Ver os números em ELTIS, David e RICHARDSON, David. A New Assessment of the Transatlantic Slave Trade. In: ELTIS, David; RICHARDSON, David (Orgs.). Extending the Frontiers: Essays on the New Transatlantic Slave Trade Database. New Haven e Londres: Yale University Press, 2008. p. 46-47.
} 
à alfandega como destino portos na costa de Angola, mas de fato seguiam para a Costa da Mina. Parte dos dados do Slave Voyages se baseia, entáo, em declaraçóes fraudulentas registradas nos passaportes emitidos na Bahia. Alexandre Ribeiro encontrou que $74 \%$ dos navios apresados pelos ingleses nas águas do golfo do Benim entre 1822 e 1830 tiveram seus passaportes emitidos para os entrepostos de Molembo e Cabinda, no litoral angolano. ${ }^{16} \mathrm{Eu}$ calculo, por baixo, que devamos por isso acrescentar aos números do tráfico oriundos da Costa da Mina pelo menos 100 mil cativos que foram parar na conta do tráfico angolano, o que reduz bastante, para apenas $2 \%$, a diferença entre os números do século XVIII e os do século XIX apontados acima para a exportação de gente da Costa da Mina. Lovejoy prega que o comércio de escravos na África Ocidental "perdeu importância devido às mudanças internas associadas à consolidação de governos de caráter islâmico que condenavam a venda de muçulmanos" (p. 44), o que não é verdade, pelo menos para o comércio brasileiro. O comércio diminuiu alguma coisa, mas não "perdeu a importância". No que Lovejoy pode estar correto é que esses números pudessem ser bem maiores, diante do aumento da produção de escravos pelos regimes do jihad e que não foram destinados ao tráfico transatlântico, mas usados internamente (Lovejoy, p. 47-48). Decisivo para a ausência de Sokoto no tráfico transatlântico talvez fosse — talvez! — que seus dirigentes não conseguiram conquistar o litoral da Costa da Mina, onde estavam os entrepostos negreiros. Tentaram, via Ilorin, mas não conseguiram. ${ }^{17}$

A seção sobre biografias é outro momento curioso de Lovejoy nas páginas da Topoi. Ali um parágrafo aponta, como se fora novidade, nomes e fontes presentes - à exceção de uma - em Rebeliäo escrava (Samuel Crowther, Ali Eisami, Francis de Castelnau, 'Abdurrahman al-Baghdádi); ou se refere a informaçóes exaustivamente usadas por mim da documentação primária relativa às revoltas baianas. Para escrever biografias, Lovejoy aconselha: "Há também numerosos testemunhos dos envolvidos no levante dos malês de 1835 e de alguns muçulmanos que náo fizeram parte nesse movimento" (p. 58). Não diga! Como compus todo um capítulo com minibiografias de malês, baseado em grande parte nesses testemunhos, corri meus olhos para a nota 65 do artigo de Lovejoy, e nada de Joáo Reis. O primeiro parágrafo daquele meu capítulo termina assim: "Seguem entâo minibiografias desses alufás", e me estendo por 21 páginas a traçar perfis desses líderes muçulmanos. ${ }^{18} \mathrm{O}$ primeiro trabalho citado por Lovejoy na nota 65 é uma dissertação de mestrado sobre a revolta baiana de 1835, de uma aluna de sua universidade, talvez orientanda dele, cujo subtítulo, por acaso, é "mini-biographies of leaders and others accused" (p. 58, nota 65). Interessante!

${ }^{16}$ RIBEIRO, Alexandre Vieira. The Transatlantic Slave Trade to Bahia, 1582-1851. In: ELTIS, David; RICHARDSON, David. (Orgs.). Extending the Frontiers. New Haven: Yale University Press, 2008. p. 139, e p. 141 (Tabela 4.4).

${ }^{17}$ REIS, João José, op. cit., 2003, p. 172-173, e bibliografia ali indicada.

${ }^{18}$ REIS, João José, ibidem, cap. 9 (citação p. 283). Esse capítulo, mais reduzido, se encontra também na edição em inglês, Slave Rebellion, cap. 7. 
Mais adiante Lovejoy escreve uma frase sobre um personagem a respeito de quem escrevi um livro todo (em coautoria com Flávio Gomes e Marcus Carvalho). Ele ensina: "Rufino José Maria, cujo nome africano, Abuncare, provavelmente indica Abu, abreviação de Abubakar, e 'Ncare', contração de Birnin Konni (N'Care = N'Konni), uma cidade fortificada no norte de Sokoto, não estava envolvido na revolta na Bahia porque ele estava no sul do Brasil na época” (p. 59). O autor está tratando de identidade, de origem, quis dizer que Rufino seria de Birnin Konni, e garante que se ele estivesse na Bahia em 1835 teria participado da revolta. Não vou entrar no mérito da adivinhação etimológica do autor (N'Koni vem a dar N'Care!), nem da adivinhação sobre o que teria feito Rufino em 1835 se estivesse na Bahia. ${ }^{19}$ Sobre este último ponto, basta lembrar que nem todo muçulmano se envolveu na revolta, inclusive entre os malês como ele. Fico na sua douta proposta sobre a origem do personagem, porque é disso que se trata. Ora, sob interrogatório da polícia recifense, em 1853, Rufino disse ser "natural de Oió", o reino iorubá, onde tinha mãe e pai cujos nomes iorubás declinou; em outros documentos sua nação é descrita ora como mina, ora, e mais especificamente, como nagô (que seria a nação de alguém de Oyo); e quando ele visitou Serra Leoa se estabeleceu em Fourah Bay, o distrito iorubá-aku-nagô-malê da colônia inglesa sobre o qual existe um capítulo inteiro em $O$ alufá Rufino, além de um outro sobre Serra Leoa no tempo da visita de Rufino. ${ }^{20}$ Lovejoy pensa saber mais sobre de onde viera Rufino do que este próprio. Embora referencie o livro em suas notas, ele demonstra não ter lido $O$ alufá Rufino, daí não perceber nele a inevitável presença da África na biografia atlântica que Reis, Gomes e Carvalho traçam do personagem. Neste livro alguns capítulos são especificamente dedicados à África, mas Lovejoy não inclui seus autores entre outros — inclusive ele próprio, naturalmente - que "colocam a África no centro de seus estudos e seguem biografias de indivíduos em contextos históricos específicos, da melhor forma que podem ser reconstruídas” (p. 66). Quando algum dia conseguir ler $O$ alufá Rufino, o historiador provavelmente achará que nossa "reconstrução" da vida de Rufino terá sido inadequada.

Quem já me leu sabe que enfatizo a dimensão étnica da Revolta dos Malês sem negligenciar o enorme peso da questấo religiosa, inclusive de como o Islã teria funcionado para moldar a identidade nagô na Bahia. Em Rebelião escrava escrevi quatro capítulos especificamente sobre a religiáo dos malês, seus líderes e seu papel na revolta (capítulos 6 a 9). Encerro o capítulo 8 assim: "Para eles [os malês] ..., além da dimensão religiosa, que certamente teve,

\footnotetext{
${ }^{19}$ Outra coisa: na nota 66 referente a este trecho, o historiador escreve: "Um problema similar é encontrado em REIS", e cita um artigo meu, Domingos Pereira Sodré, un prêtre africain dans la Bahia du XIXe siècle. In: HÉBRARD Jean (Org.). Brésil; quatre siècles d'esclavage. Paris: Karthala, 2012. p. 165-215. Qual "problema similar" exatamente? Nenhum esclarecimento.

${ }^{20}$ REIS, João José; GOMES, Flávio dos Santos; CARVALHO, Marcus J. M. de. O alufá Rufino: tráfico, escravidão e liberdade no Atlântico negro (c. 1822-c. 1853). São Paulo: Companhia das Letras, 2010, passim (ver por exemplo a transcrição do interrogatório na p. 367) e capítulos 14 e 15 sobre Serra Leoa. Quanto ao nome muçulmano de Rufino, referido na imprensa como Abuncare, estaria mais próximo, por exemplo, de Abdul ou Abu Karin (O alufá, p. 9).
} 
a rebeliáo se caracterizou por outros importantes fatores que se entrelaçaram com o religioso. O fator étnico foi um deles." ${ }^{21} \mathrm{O}$ próprio termo malê é etnicamente específico, derivado de ìmàle (ou imàlẹ, imòle, imòṇle), muçulmano em língua iorubá; o grito de guerra ouvido nas ruas no momento do levante foi "Viva nagô"; a maioria esmagadora dos membros dos círculos muçulmanos envolvidos na conspiração era nagô; os mestres muçulmanos identificados como protagonistas da revolta eram, na sua quase totalidade, nagôs; entre os presos, 149 (83\%) dos escravos e $60(53,6 \%)$ dos libertos (ao todo $72,6 \%$ ) eram nagôs.

Muitos contemporâneos inflacionaram a participação dos haussás em 1835, e eu discuto suas razôes. Em resumo, os haussás compunham 10,5\% dos prisioneiros, eram esmagadoramente libertos ( 23 em comparação com oito escravos), a quem as autoridades quiseram atingir com prioridade pelo perigo potencial que representavam na organização de revoltas (podiam se deslocar mais livremente, possuíam ou alugavam casas onde reunir conspiradores etc.). Acrescente-se que as autoridades tinham a lembrança de revoltas anteriores levadas a cabo pelos haussás, e que eles eram considerados os típicos muçulmanos, inclusive pelo conhecido letramento de alguns. Mas no decorrer do inquérito o quadro de militância haussá se desfez: dos 31 presos dessa nação, apenas três foram no final sentenciados. O único mestre haussá, Elesbão do Carmo, ou Dandará, que declarou ter sido malam em sua terra, foi preso, interrogado, pronunciado, mas não teve seu nome incluído no libelo acusatório, nem foi sentenciado. Suspeito que, ao contrário de outros mestres muçulmanos, conseguiu provar sua inocência; ou, se participou da conspiração, seria exceção e não regra quanto ao envolvimento haussá no movimento. $\mathrm{O}$ único mestre claramente envolvido que não era nagô, Luis Sanim, presidia um núcleo conspiratório inteiramente nagô, disse falar fluentemente a língua dos nagôs, mas (atentem!) declarou ser tapa e não nagô. Não apenas nagôs fizeram o levante - e entre estes, não apenas nagôs islamizados -, o que afirmo é que a participação haussá, a maior naçáo muçulmana na época na Bahia, foi desconcertantemente pequena no levante. Escrevi: "A identidade malê era uma identidade islâmica nagô. Haussá? Haussá era mussulmi." Segundo Castelnau fonte que Lovejoy gosta de usar e confia - os haussás que ele entrevistou na Bahia no final da década de 1840 tinham os malês como infiéis. ${ }^{22}$ Aliás, não disputo que os haussás fossem melhor treinados na crença muçulmana do que os nagôs, questiono que tivessem emprestado direção intelectual e política ao movimento de 1835, como haviam feito em movimentos anteriores, em 1807 e 1814, por exemplo. Isso está discutido, com detalhes e nuances, em Rebelião escrava.

Lovejoy evita o debate direto sobre este assunto. Propóe que, no contexto da revolta de 1835, haussá era nagô, e por extensão malê era o mesmo que mussulmi, o que não encontra sustentaçáo nos documentos baianos, nem na história africana. Se aqueles que se declara-

\footnotetext{
${ }^{21}$ REIS, João José, op. cit., 2003, p. 282 (a ênfase não está no original).

${ }^{22}$ Para detalhes, REIS, João José, ibidem, cap. 10 (citação p. 349) e a referência a Castelnau na p. 177.
} 
ram nagôs durante a devassa podiam também ser haussás, quem seriam os haussás que se declararam haussás?

Na própria Ilorin — onde foram ora aliados, ora adversários, ora aliados novamente — haussás e iorubás/nagôs viviam em quarteirôes separados, não importa que um falasse a língua do outro, não se sabe com que destreza, ou que comungassem a mesma religião. Aliados aos fulanis, os haussás sufocaram os muçulmanos iorubás liderados por Solagberu após terem derrotado o partido do pagáo Afonjá e eliminado a este. As clivagens étnicas foram, em grande parte, trazidas da África dos malês para a Bahia. ${ }^{23} \mathrm{Na}$ África elas se encontram, por exemplo, nas lembranças de Samuel Crowther, uma fonte que Lovejoy distorce. Ele diz que o futuro bispo anglicano, natural da cidade de Oșogun, na periferia do reino de Oyo, "atribuiu a destruição de muitas cidades de Oyo na década de 1820 a muçulmanos de Oyo, a quem ele chamou de fulanis, embora muitos falassem iorubá" (p. 54). Infelizmente, Lovejoy não remete a uma página específica da obra de Crowther citada para sustentar sua ideia. Ocorre que Crowther distinguiu os "maometanos de Oyo" dos "Foulahs" (fulanis) - e chega a narrar um episódio nada amistoso entre indivíduos de um e outro grupo ${ }^{24}$-, mas também, num outro momento, acrescentaria à lista dos seus "inimigos" mais um personagem coletivo: "os escravos estrangeiros", se referindo aos escravos de Oyo que se levantaram em 1817 e eram na sua maioria haussás, embora não só. Ou seja, Crowther distingue muçulmanos iorubás, fulanis e haussás. ${ }^{25}$

O alufá Rufino também disse ter sido capturado por haussás, ele que era muçulmano nagô, ou seja, malê. Segundo uma testemunha a seu interrogatório de 1853, ele disse ter "sido aprisionado na guerra pelos Ussás [...]", decerto referindo-se aos mesmos "escravos estrangeiros" de Crowther. ${ }^{26}$ Enquanto os nativos sabiam distinguir quem era quem nos conflitos em curso naquela regiẫo, o viajante estrangeiro capitão Hugh Clapperton, ele sim, desavisadamente chamaria de "Fellatas", ou fulanis, aos muçulmanos em geral (iorubás, fulanis, haussás) que pilhavam Oyo naquela altura (Lovejoy, p. 54). Ainda assim, Clapperton escreveu que aos "escravos haussás" rebeldes "se reuniram muitos Fellatas" — ambos os grupos aderentes do Islâ, uns mais que outros - , dando a entender que aprendeu alguma coisa com os nativos sobre as diferenças étnicas, apesar do manto da religiáo comum, no conflagrado território de Oyo e em Ilorin. ${ }^{27} \mathrm{Ou}$ seja, dois testemunhos desse conflito - o

\footnotetext{
${ }^{23}$ REIS, João José, ibidem, cap. 6, e bibliografia ali referida.

${ }^{24}$ Ver REIS, João José, ibidem, p. 169.

${ }^{25}$ Palavras de Crowther: "Os inimigos que levaram a cabo essas guerras eram principalmente os maometanos de Oyo, os quais abundam em meu país - se uniram com os Foulahs e aqueles escravos estrangeiros que escaparam de seus senhores, formando uma força de cerca de 20.000 que perturbaram todo o país." Ver Letter of Mr. Samuel Crowther to the Rev. William Jowett, in 1837. In: Journals of the Rev. James Frederick Schön and Mr Samuel Crowther. 2. ed. Londres: Frank Cass, 1970 [orig. 1842]. p. 372.

${ }^{26}$ REIS, João José; GOMES, Flávio dos Santos; CARVALHO, Marcus J. M. de, op. cit., p. 372.

${ }^{27}$ CLAPPERTON, Hugh. Journal of a Second Expedition into the Interior of Africa from the Bight of Benin to Soccatoo. Londres: Frank Cass, 1966 [orig. 1829]. p. 61, 62, por exemplo, e citação p. 18. O assistente
} 
de Crowther e o de Clapperton - que Lovejoy usa para fazer convergir uma identidade étnica radicada na religiáo, a identidade fulani, na verdade distinguiram os fulanis de outros grupos locais, sobretudo de iorubás e haussás, apesar de poderem supostamente falar uns as línguas dos outros e comungar da mesma religião.

Ao desembarcarem na Bahia, entre 1817 e 1835, os haussás vindos de Oyo e Ilorin tinham como se integrar às redes sociais dos haussás chegados em levas anteriores muito mais volumosas. Os haussás como um todo, na altura de 1835, não formavam uma nação pequena, eram relativamente numerosos (estimei-os em mais de 2 mil almas, entre escravos e libertos, cerca de $10 \%$ dos africanos em Salvador), ${ }^{28}$ tinham, além de uma comunidade linguística, sentimento de origem e religiáo (embora nem todos fossem muçulmanos e, destes, nem todos jihadistas) que os congregavam, apesar de, quanto ao último item, numerosos terem se convertido ao catolicismo, sendo preciso investigar se isso os apartou radicalmente de seus irmãos islamitas. Então, à exceção de um ou outro com problemas de identidade - eu encontrei um que se dizia ora mina, ora haussá ${ }^{29}$ —, os africanos não se confundiam quanto a serem nagô ou haussá no ambiente baiano dos malês. ${ }^{30}$

Não dá para negligenciar o peso da identidade étnica — ou da identidade de nação - na concepção, mobilização e execução do movimento de 1835 . E não existia exata convergência entre religião islâmica e nação africana, pois mesmo entre os haussás havia gente pagá, gente aderente ao bori e gente que trocara o islamismo pelo catolicismo, e mesmo, é provável, quem circulasse entre as diversas crenças. Majoritariamente não muçulmana, a nação nagô tinha um setor muçulmano, portanto nação não equivalia a religião, com o que quero dizer que mulçumanas ou não as pessoas "iorubás" se diziam nagôs.

Minha metodologia para estabelecer pertencimento às naçôes africanas em 1835 foi analisar as declaraçôes dos próprios acusados durante os interrogatórios. Autoidentificação, identidade êmica. Embora os termos étnicos das naçôes tivessem sido criados no circuito do tráfico, por um processo de ladinização - que muitos preferem chamar crioulização —, os africanos terminaram por adotá-los, uma complexa operação de etnogênese que não cabe aqui detalhar. Basta lembrar que a naçáo nagô, por exemplo, era uma espécie de federaçáo que servia de guarda-chuva identitário a indivíduos e grupos oriundos dos qua-

de Clapperton, Richard Lander, também aprendeu que "Falatah" e haussá eram grupos diferentes. Ver LANDER, Richard. Records of Captain's Clapperton Last Expedition to Africa. Londres: Frank Cass, 1967 [orig. 1830], v. 1, p. 96-97, 290, apenas a título de exemplo.

${ }^{28}$ REIS, João José, op. cit., 2003, p. 327.

${ }^{29}$ REIS, João José, ibidem, p. 585, n. 74.

${ }^{30}$ Evito aqui debater as revoltas haussás das primeiras décadas do século XIX, assunto de que trato desde minha tese de doutorado de 1982, e antes de mim outros autores o fizeram, inclusive Nina Rodrigues, $O s$ africanos no Brasil, cap. 2, que escreveu na virada do século XX. No entanto, Lovejoy escreve que "Schwartz foi pioneiro em enfatizar a ligação entre as revoltas na Bahia e a migração hausa (sic)” (p. 64). Já que ele não o abona em nota, imagino que se refira ao livro de Schwartz, Sugar Plantations, publicado em 1985 (e em cujas referências está a minha tese, por ele orientada), e desconheço autor com este nome que tivesse escrito sobre as revoltas baianas antes de Nina. 
tro cantos da iorubalândia, que falavam idioma comum, embora com sotaques diferentes, e tinham outros traços culturais a uni-los, entre os quais mitos de criação do povo iorubá. Seus membros, entretanto, guardavam a memória de origens e identidades específicas e, por isso, alguns deles, ao serem interrogados, se disseram nagô-ba (de Egba), nagô-jexá (de Ilesha), nagô-jabu (de Ijebu). Mas não encontrei nenhum nagô-uçá na documentação da devassa ou fora dela. Assim falou o escravo nagô Antonio: "Ainda que todos são nagôs, cada um tem sua terra." ${ }^{31}$ Indivíduos pertencentes a algumas naçôes pouco numerosas que não era o caso dos haussás - podiam participar das redes sociais e religiosas nagôs ou haussás. Encontrei um nagô-tapa, por exemplo; mas um só, pois tapa, termo como os iorubás chamavam aos vizinhos nupes, era uma identidade distinta adotada por estes africanos na Bahia. ${ }^{32}$

As identidades em torno da noção de nação eram amiúde fluidas, contextuais, relacionais, estratégicas, mas não arbitrárias. Assim, quer pela experiência africana, quer pela baiana, é arbitrário atribuir identidade nagô (ou "iorubá") a indivíduos que se identificavam como haussás na África. Os haussás permaneciam haussás na Bahia, apesar de — como os nagôs - oriundos de reinos os mais diversos e de muitos terem vivido às vezes longos anos em território iorubá (leia-se, sobretudo, Oyó). Que haussás falassem a língua iorubá não resolve a questão, como quer Lovejoy (p. 62), porque, na mesma conjuntura de 1835, africanos houve - e até crioulos - que declararam falar aquela língua ao mesmo tempo que diziam pertencer a naçôes que não a nagô. Falar a língua do outro, ou abraçar a mesma religião, não torna alguém o outro. Isso é elementar.

Não me reconheço embarcado em "tentativa simplista de associar a etnia exclusivamente com a língua" (p. 62), Lovejoy pode dormir tranquilo quanto a isso. A identidade étnica era amiúde acompanhada de outros sinais diacríticos, aliás apontados por Lovejoy, mas que também explorei em Rebelião escrava e outros trabalhos meus, a exemplo do inventário de nomes próprios que arrolei e busco interpretar. ${ }^{33}$ Também faço um esforço para tentar decodificar, como sinais de pertencimento étnico, as escarificaçôes faciais descritas nos autos de prisão dos suspeitos de 1835 .

Sobre este último tema, Lovejoy escreve em seu artigo na Topoi: "Escarificaçôes faciais e corporais eram praticadas como um meio de identificação, inclusive como proteção contra a escravidão, além de representarem rituais de solidariedade da comunidade" (p. 61). Lovejoy estava nesse momento dando uma volta pela África antes de chegar à Bahia de 1835, mas achei essa frase familiar porque penso o mesmo desde pelo menos 2003, quando também fiz meu passeio pela África para escrever umas quatro páginas sobre escarificações entre os suspeitos de rebeldia. ${ }^{34}$ Achei estranho que, na referência em nota, Lovejoy assumisse a

\footnotetext{
${ }^{31}$ REIS, João José, op. cit., 2003, p. 307.

${ }^{32}$ REIS, João José, ibidem, p. 339 e bibliografia ali indicada.

${ }^{33}$ REIS, João José, ibidem, p. 315-319, e bibliografia ali indicada.

${ }^{34}$ Ver REIS, João José, ibidem, p. 311-315.
} 
ideia como inteiramente sua, pois cita como fonte um trabalho seu. Este trabalho, no entanto, plagia (com alguma paráfrase), quiçá por displicência, dois parágrafos de um capítulo que escrevi em parceria com Beatriz Mamigonian. Essa é uma acusação tão grave que, para dissolver dúvidas, ofereço imediatamente a prova ao leitor nas imagens que seguem. ${ }^{35} \mathrm{Em}$ primeiro lugar, Lovejoy:

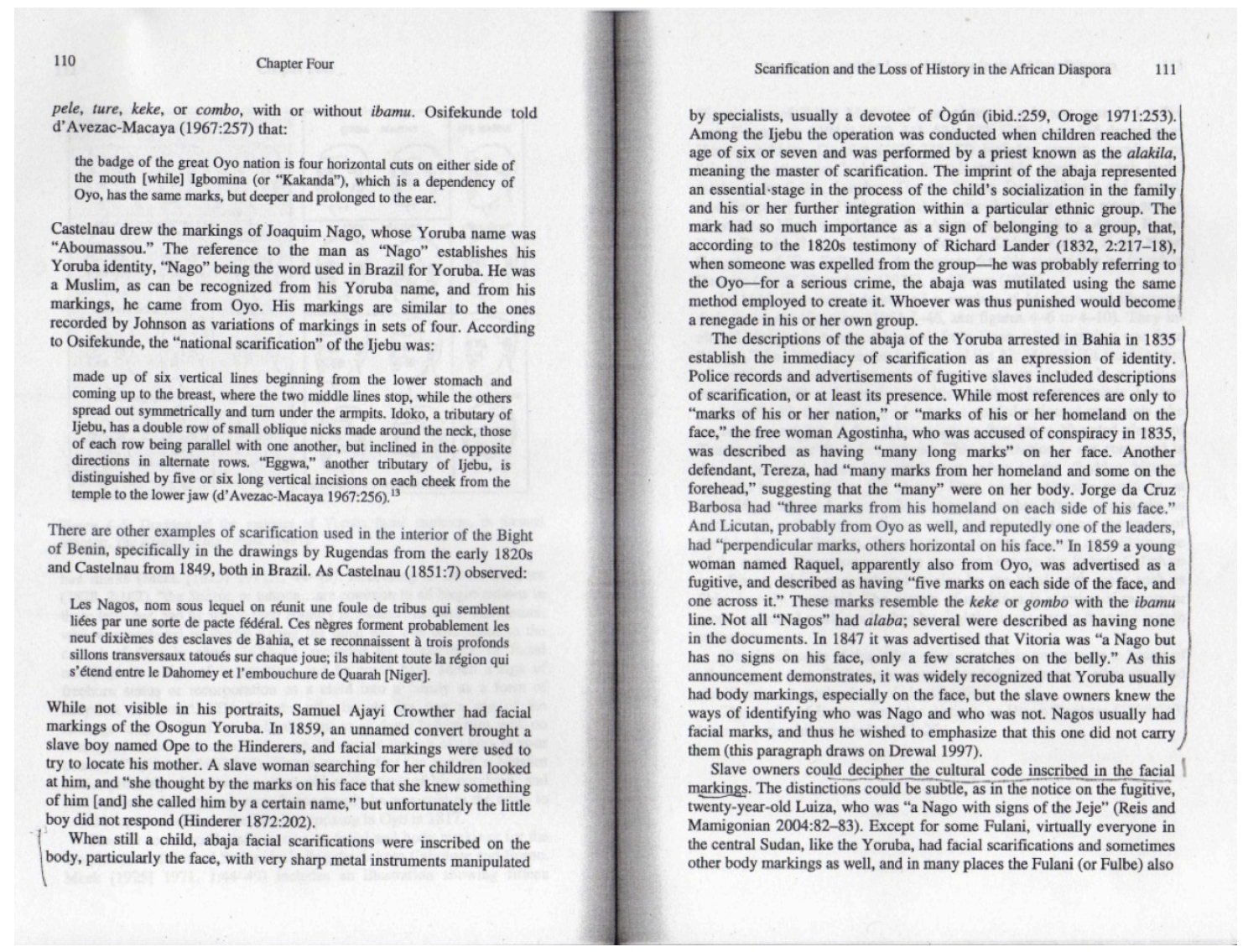

E agora, Reis e Mamigonian:

${ }^{35}$ Imagens reproduzidas de, respectivamente, LOVEJOY, Paul. Scarification and the Loss of History in the African Diaspora. In: APTER, Andrew; DERBY, Lauren (Orgs.). Activating the Past Historical memory in the Black Atlantic. Newcastle: Cambridge Scholarly Publishing, 2010. p. 99-138 (o plágio está na p. 110-111); e REIS, João José; MAMIGONIAN, Beatriz Gallotti. Nagô and Mina: The Yoruba Diaspora in Brazil. In: FALOLA, Toyin; Childs, Matt (Orgs.). The Yoruba Diaspora in the Atlantic World. Bloomington: Indiana University Press, 2004. p. 77-110 (trechos plagiados na p. 82-83). 


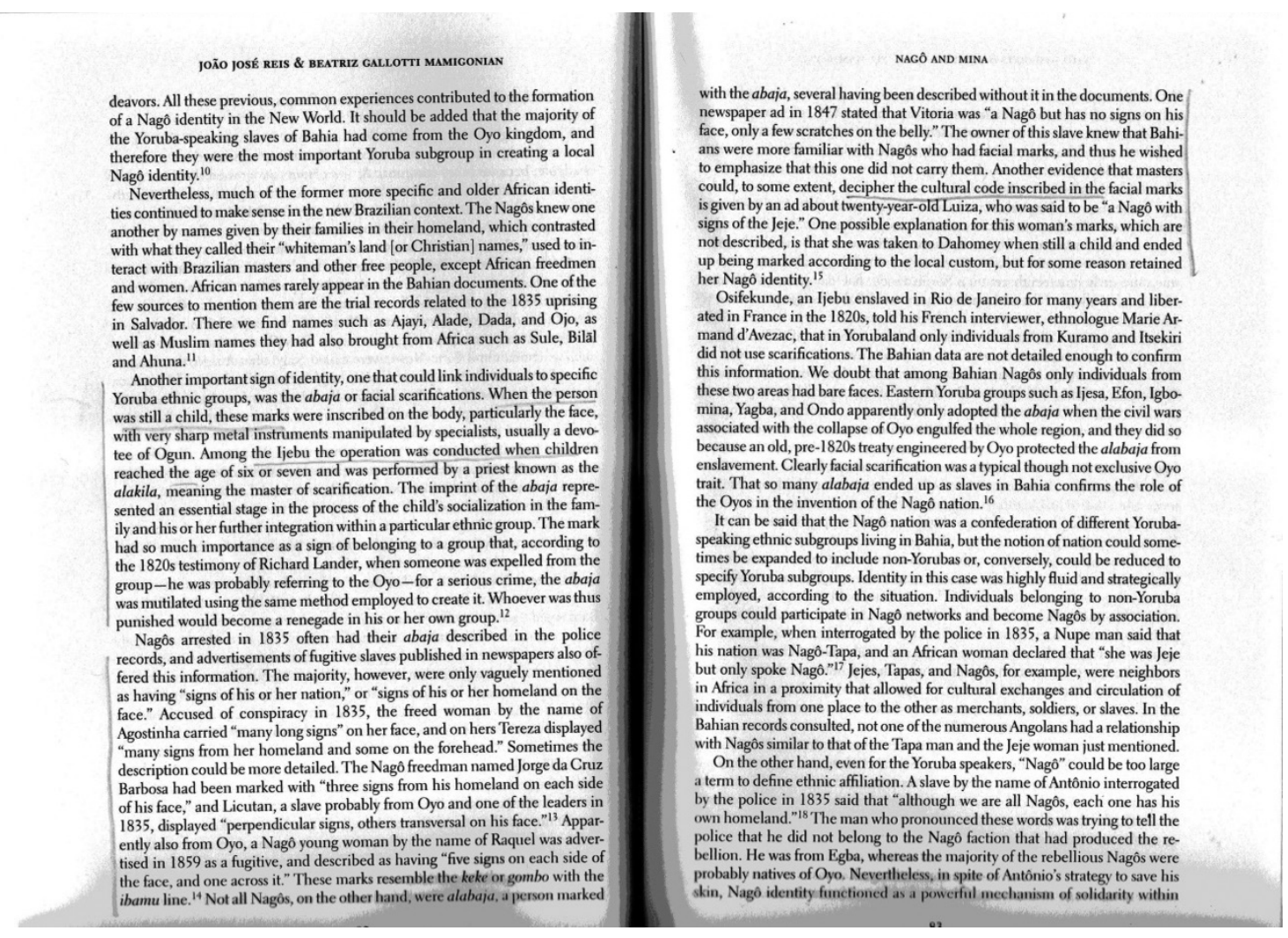

Vejam só que ironia, Lovejoy a plagiar trechos africanistas do cara que náo entende de África! Ele lê com desleixo — quando lê — não apenas outros autores, lê assim a si próprio! Senão como entender que náo consiga distinguir o que escreve do que escrevem os outros? Lovejoy chega a citar nosso artigo a certa altura, mas sem dar o devido crédito da autoria desses dois parágrafos. Valerá a pena o leitor consultar ambos os artigos, ou capítulos de coletâneas, porque o plágio se estende às notas. A esse propósito, no final do segundo parágrafo plagiado, Lovejoy ainda escreve: "este parágrafo recorre a Drewal 1997." O historiador da arte africana Henry Drewal é, na verdade, fonte devidamente citada na nota 12 de nosso artigo. Mesmo se tivesse escrito, "este parágrafo recorre a Reis e Mamigonian", o trecho deveria ser acompanhado de algumas aspas de atribuição autoral. Espero que sejamos os únicos autores assim predados pelo versátil africanista, até porque tenho utilizado seus escritos para compor minhas impressões sobre alguns aspectos da história da África. ${ }^{36}$

Qualquer leitor do artigo de Paul Lovejoy na Topoi ficará impressionado com a longa lista de títulos que compóem suas notas de rodapé. Mas o leitor especializado amiúde encontrará desajuste entre o que é discutido no texto e o que é referenciado em nota, entre outros desvios do protocolo acadêmico. ${ }^{37}$ Às vezes se afigura um exercício algo desorganizado de

\footnotetext{
${ }^{36}$ Sete títulos dele estão listados em REIS, João José, op. cit., 2003, p. 629.

${ }^{37}$ Ver, por exemplo, texto e nota 57 na p. 56 do artigo de Lovejoy. Ainda sobre o que Lovejoy escreve nesta
} 
engordar notas. Consideremos, só por hipótese, que as obras citadas tenham sido "lidas" do jeito que foram as minhas e as de alguns autores mal lidos que me dei ao trabalho de checar - a conclusão seria que ali estão em grande parte referenciadas com o intuito de demonstrar erudição bibliográfica para estabelecer autoridade acadêmica e impor poder intelectual. Seria este o segredo do "método" erudito pregado por Paul Lovejoy ("incluir mais bibliografia nas nossas análises", p. 59) e empregado ao longo de seu artigo?

$\mathrm{Eu}$ poderia me estender muito mais sobre outros pontos inconsequentes do artigo de Lovejoy, mas acho que o recado está dado.

\section{Referências Bibliográficas}

CLAPPERTON, Hugh. Journal of a Second Expedition into the Interior of Africa from the Bight of Benin to Soccatoo. Londres: Frank Cass, 1966 [orig. 1829].

COSTA e SILVA, Alberto da. Sobre a rebelião de 1835 na Bahia. Revista Brasileira, ano viii, n. 31, p. 9-33, 2002.

DIOUF, Sylviane. Servants of Allah: African Muslims Enslaved in the Americas. Nova York e Londres: New York University Press, 1998.

ELTIS, David e RICHARDSON, David. A New Assessment of the Transatlantic Slave Trade. In: ELTIS, David; RICHARDSON, David (Orgs.). Extending the Frontiers: Essays on the New Transatlantic Slave Trade Database. New Haven e Londres: Yale University Press, 2008, p. 1-60.

GENOVESE, Eugene. From Rebellion to Revolution: Afro-American Slave Revolts in the Making of the New World. Nova York: Vintage, 1979.

. Roll Jordan Roll: The World the Slaves Made. Nova York: Pantheon, 1974.

GOMEZ, Michael A. Black Crescent: The Experience and Legacy of African Muslims in the Americas. Cambridge: Cambridge University Press, 2005.

HOBSBAWM, Eric. The Age of Revolution, 1789-1848. Nova York: Abacus, 1977 [orig. 1962].

LANDER, Richard. Records of Captain's Clapperton Last Expedition to Africa. Londres: Frank Cass, 1967 [orig. 1830].

LOVEJOY, Paul. Scarification and the Loss of History in the African Diaspora. In: APTER, Andrew; DERBY, Lauren (Orgs.), Activating the Past Historical memory in the Black Atlantic. Newcastle: Cambridge Scholarly Publishing, 2010, p. 99-138. 
. Resenha de Slave Rebellion in Brazil: The Muslim Uprising of 1835 in Bahia. Baltimore: The Johns Hopkins University Press, 1993. In: The International Journal of African Historical Studies, v. 30, n. 1, p. 183-184, 1997.

MELLO e SOUZA, Laura de; REIS, João José. Popular Movements in Colonial Brazil. In: CANNY, Nicholas; MORGAN, Philip (Orgs.). The Oxford Handbook of the Atlantic World, 1450-1850. Oxford e Nova York: Oxford University Press, 2011, p. 550-566.

RAMOS, Artur. As culturas negras no Novo Mundo. São Paulo: Companhia Editora Nacional, 1979 [orig. 1937].

REIS, João José; MAMIGONIAN, Beatriz Gallotti. Nagô and Mina: The Yoruba Diaspora in Brazil. In: FALOLA, Toyin; CHILDS, Matt (Orgs.). The Yoruba Diaspora in the Atlantic World. Bloomington: Indiana University Press, 2004, p. 77-110.

. Domingos Pereira Sodré, un prêtre africain dans la Bahia du XIXe siècle. In: HÉBRARD, Jean (Org.). Brésil; quatre siècles d'esclavage. Paris: Karthala, 2012, p. 165-216. . Um balanço dos estudos sobre as revoltas escravas da Bahia. In: REIS, João José (Ed.). Escravidão e invenção da liberdade: estudos sobre o negro no Brasil. São Paulo: Brasiliense, 1988, p. 87-140.

. Rebeliāo escrava. São Paulo: Companhia das Letras, 2003.

. Slave Rebellion in Brazil: The Muslim Uprising of 1835 in Bahia. Baltimore: The Johns Hopkins University Press, 1993.

REIS, João José; GOMES, Flávio dos Santos; CARVALHO, Marcus J. M. de. O alufá Rufino: tráfico escravidão e liberdade no Atlântico negro (c. 1822-c. 1853). São Paulo: Companhia das Letras, 2010.

RIBEIRO, Alexandre Vieira. The Transatlantic Slave Trade to Bahia, 1582-1851. In: ELTIS, David; RICHARDSON, David (Orgs.). Extending the Frontiers. New Haven e Londres: Yale University Press, 2008.

RODRIGUES, Nina. Os africanos no Brasil. 4. ed. São Paulo: Companhia Editora Nacional, 1976.

SCHÖN, Frederick; CROWTHER, Samuel. Journals of the Rev. James Frederick Schön and Mr Samuel Crowther. 2. ed. Londres: Frank Cass, 1970 [orig. 1842].

SCHWARTZ, Stuart. Sugar Plantations in the Formation of Brazilian Society: Bahia, 15501835. Cambridge: Cambridge University Press, 1985. 